\title{
Callus Formation and Regeneration of Adventitious Embryos from Celery Microspores by Anther and Isolated Microspore Cultures
}

\author{
Norio Dohya, Sachiko Matsubara and Kenji Murakami \\ Department of Agricultural Sciences, Faculty of Agriculture, Okayama University, Tsushima, Okayama 700
}

\begin{abstract}
Summary
Anthers and microspores of Apium graveolens L. (celery) were cultured in vitro to obtain haploid plants.

Anther culture: Immature anthers of 'Cornell $619^{\prime}$ ' and 'Cornell 19' at three stages of development were cultured on eight different media containing a half strength of Murashige and Skoog (1/2 MS) and B5 media supplemented with combinations of 2, 4-D, BA, NAA, and zeatin plus sucrose and Gelrite from May to June in 1994.

Calli developed from 'Cornell 19' microspores at tetrad stage on 1/2 MS medium supplemented with 2,4-D and B5 medium supplemented with 2,4-D. In 'Cornell 619', calli developed from tetrad microspores on B5 medium supplemented with 2, 4-D, and from early uninucleous microspores on B5 medium supplemented with 2, 4-D. Adventitious embryos regenerated from calli transferred to MS medium with or without NAA and BA; plantlets grew after 40 to 60 days.

Isolated microspore culture: Celery microspores at different developmental stages were cultured in liquid B5, NLN, and 1/2 MS media supplemented with 2,4-D and BA, with or without glutamine and with serine at the density of $2.5 \times 10^{3}$ microspores $/ \mathrm{m} l$ medium. In 'Cornell 619', many microspores of early uninucleate stage developed to colonies in the B5, NLN, and $1 / 2$ MS media; the colonies in B5 and $1 / 2$ MS media developed into heartshaped embryos; microspores, plated in modified 1/2 MS medium supplemented with 2 , 4-D and BA, developed colonies and calli.
\end{abstract}

\section{Introduction}

Production of new celery cultivars by hybridization is tedious work, because the flowers are very small. Haploid plants have the advantage of the possibility of accelerating the production of homozygous lines and detecting recessive mutations. Although anthers and microspore cultures have been used successfully to produce haploid plants in many plant species (Bajaj, 1983), there are few successes in the Umbelliferae family. The formation of haploid plants in carrot by anther culture has recently been reported by Andersen et al. (1990), Hu et al. (1993) and Matsubara et al. (1995), but that in celery has not.

This study reports the production of plantlets by anther culture, and haploid embryo and callus

Received; May 8, 1995. Accepted; July 29. 1996.

This paper was presented at the Spring Meeting of the Japanese Society for Horticultural Science. Chiba, 1995. formation by microspore culture in celery.

\section{Materials and methods}

\section{Anther culture}

Anthers of celery 'Cornell 619' and 'Cornell 19' were obtained from plants grown in the field of Okayama University by forcing inflorescences from May 6 to June 23, 1994. Immature anthers of center florets at the tetrad, early uninucleate and late uninucleate stages from young inflorescences (Fig. 1) were collected in the morning. They were surface-sterilized for $10 \mathrm{sec}$ in $70 \%$ ethanol, immersed in sodium hypochlorite $(1 \%$ available Cl) for $15 \mathrm{~min}$, rinsed thrice with sterile distilled water, and plated on a basal media consisting of a half strength-MS (Murashige and Skoog, 1962) (1/2 MS) and B5 (Gamborg et al., 1968) (B5), supplemented with $30 \mathrm{~g} \cdot \mathrm{liter}^{-1}$ sucrose, $2 \mathrm{~g} \cdot \mathrm{liter}^{-1}$ Gelrite, and 0.5 or $1.0 \mathrm{mg} \cdot$ liter $^{-1} 2,4-\mathrm{D}$ and 0 or 


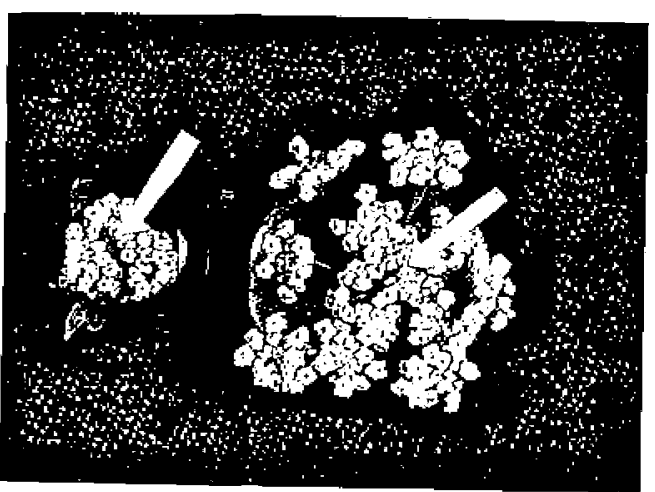

Fig. 1. Stages 1 (left) and 2 (right) of celery inflores. cence. Arrows indicate center florets used.

$0.1 \mathrm{mg} \cdot$ liter $^{-1} \mathrm{BA}$. A factorial design with eight combinations was employed. After adjusting the $\mathrm{pH}$ of the media to 5.8, they were autoclaved for $15 \mathrm{~min}$ at $120{ }^{\circ} \mathrm{C}$. About 40 anthers were plated on $5 \mathrm{ml}$ of medium in a petri dish $(60 \times 15 \mathrm{~mm})$. Three dishes with 80-120 anthers were sealed with Parafilm per treatment. Cultures were incubated at $25^{\circ} \mathrm{C}$ under $16-\mathrm{hr}$ photoperiod provided with $20 \mu \mathrm{mol} \cdot \mathrm{sec}^{-1} \cdot \mathrm{m}^{-2}$ fluorescent light for 40 - 60 days. Calli, formed on each medium, were dissected and plated in individual test tubes con taining thirty-eight kinds of media. The media con sisted of MS medium supplemented with 30 $\mathrm{g} \cdot$ liter $^{-1}$ sucrose, $2 \mathrm{~g} \cdot$ liter $^{-1}$ Gelrite and $24 \mathrm{com}$. binations of $0,0.05,0.1$, and $1.0 \mathrm{mg} \cdot \operatorname{liter}^{-1} \mathrm{NAA}$ and $0.1,0.2,0.4,0.8,1.0$, and $1.6 \mathrm{mg} \cdot \operatorname{liter}^{-1} \mathrm{BA}$, 12 combinations of 0.1 and $1.0 \mathrm{mg} \cdot$ liter $^{-1} \mathrm{NAA}$ and $0.1,0.2,0.4,0.8,1.0$, and $2.0 \mathrm{mg} \cdot \mathrm{liter}^{-1}$ zeatin and without phytohormones, and B5 medium supplemented with $30 \mathrm{~g} \cdot \mathrm{liter}^{-1}$ sucrose, 2 $\mathrm{g} \cdot$ liter $^{-1}$ Gelrite, and $1 \mathrm{mg} \cdot$ liter $^{-1}$ 2, 4-D.

Embryo culture: Embryos were transferred to MS 8 $\mathrm{g} \cdot$ liter $^{-1}$ agar solidified medium under the same condition as the anther culture. Regenerated plants were grown in vermiculite for about a month, then transplanted in soil in a plastic house.

\section{Isolated microspore culture}

Buds containing microspores at early and late uninucleate stages were surface-sterilized as were the anthers. Buds were macerated in a test tube containing $1 / 2$ MS liquid culture medium supplemented with $3 \mathrm{~g} \cdot$ liter $^{-1}(\mathrm{w} / \mathrm{v})$ sucrose and 1.0 $\mathrm{mg} \cdot$ liter $^{-1} 2,4-\mathrm{D}$ and $\mathrm{BA}$ at $\mathrm{pH}$ 5.8. Microspores which were isolated by filtration through a $38 \mu \mathrm{m}$ stainless screen were centrifuged three times at $300 \mathrm{rpm}$ for $3 \mathrm{~min}$ with fresh culture medium. The microspores were suspended in B5, Lichter's medium (NLN) (Lichter, 1982) and a half strength MS supplemented with $10 \mathrm{~g} \cdot$ liter $^{-1}$ sucrose and 1 $\mathrm{mg} \cdot \operatorname{liter}^{-1} 2,4-\mathrm{D}$ and BA, with or without 800 $\mathrm{mg} \cdot$ liter $^{-1}$ glutamine and $100 \mathrm{mg} \cdot$ liter $^{-1}$ serine at $\mathrm{pH} 5.8$ at a density of $2.5 \times 10^{3} / \mathrm{m} l$. Two milliliters of the microspore suspension were plated onto a $60 \times 15 \mathrm{~mm}$ plastic petri dish and incubated at $25^{\circ} \mathrm{C}$ under dark until many colonies were formed. Each treatment consisted of at least five replicates. Two $\mathrm{ml}$ of the same fresh medium minus sucrose were added a month. Microspores of an early uninucleate stage were plated in modified $1 / 2 \mathrm{MS}$ containing three combinations of $\mathrm{KNO}_{3}$ and $\mathrm{NH}_{4} \mathrm{NO}_{3}$ $\left(\mathrm{KNO}_{3}: \mathrm{NH}_{4} \mathrm{NO}_{3}\left(\mathrm{mg} \cdot\right.\right.$ liter $\left.^{-1}\right)$ ); 3,000:0 (Medium I), 2,161: 344 (Medium II), and 1,515: 600 (Medium III). Molarity of $\mathrm{NO}_{3}$ and $\mathrm{NH}_{4}$ was 60 $\mathrm{mM}: 0$ (Medium I), $51.4 \mathrm{mM}: 8.6 \mathrm{mM}$ (Medium II), and $45 \mathrm{mM}: 15 \mathrm{mM}$ (Medium III), and their molar ratios were $6: 0 ; 6: 1$; and $3: 1$, respectively. These modified $1 / 2$ MS media were also supplemented with $1.0 \mathrm{mg} \cdot \mathrm{liter}^{-1}$ 2, 4-D and BA at a density of $2.5 \times 10^{3}$ microspores $/ \mathrm{m} l$ medium.

\section{Results}

\section{Anther culture}

In 'Cornell 619', microspores at tetrad stage developed to a uninucleate stage in $6.7-26.6 \%$ of anthers after a 10 day culture; these initiated cell division to from calli. More mature microspores at plating time did not form callus, except 5 out of 96 anthers containing microspores at early uninucleate stage on B5 medium supplemented with $1.0 \mathrm{mg} \cdot$ liter $^{-1}$ 2, 4-D (Table 1, Fig. 2). In 'Cornell $19^{\prime}$ microspores, calli formed only from tetrad microspores on B5 medium supplemented with 1.0 $\mathrm{mg} \cdot$ liter $^{-1}$ 2, 4-D and $1 / 2$ MS medium supplemented with 0.5 and $1.0 \mathrm{mg} \cdot$ liter $^{-1} 2,4-\mathrm{D}$.

Embryo culture; Four adventitious embyros were generated from calli which originated from tetrad microspores in 'Cornell 619' (Fig. 3), and an adventitious embryo developed from a callus from an early uninucleate microspore after $40 \sim 60$ days (Table 2). The embryos upon transfer to MS basal medium grew into normal plantlets (Fig. 4). In 
Table 1. Callus formation from tetrad and uninucleate microspores by celery anther culture on 8 different media.

\begin{tabular}{|c|c|c|c|c|c|c|}
\hline \multirow{2}{*}{$\begin{array}{l}\text { Age of } \\
\text { microspore }\end{array}$} & \multirow{2}{*}{$\begin{array}{l}\text { Basal } \\
\text { medium }\end{array}$} & \multicolumn{2}{|c|}{ Phytohormones } & \multirow{2}{*}{$\begin{array}{l}\text { No. anthers } \\
\text { plated }\end{array}$} & \multicolumn{2}{|c|}{ Anthers formed callus } \\
\hline & & $2.4-D$ & $\mathrm{BA}$ & & No. & Frequency $(\%)$ \\
\hline \multicolumn{7}{|c|}{ cv. Cornell 19} \\
\hline Stage 1 & B5 & $1.0 \mathrm{mg} / \mathrm{l}$ & 0 & 86 & 4 & 4.7 \\
\hline \multirow[t]{16}{*}{ (Tetrad) } & & 0.5 & 0 & 98 & 0 & 0 \\
\hline & & 1.0 & 0.1 & 96 & 0 & 0 \\
\hline & & 0.5 & 0.1 & 93 & 0 & 0 \\
\hline & $1 / 2 \mathrm{MS}$ & 1.0 & 0 & 79 & 1 & 1.3 \\
\hline & & 0.5 & 0 & 99 & 2 & 2.0 \\
\hline & & 1.0 & 0.1 & 87 & 0 & 0 \\
\hline & & 0.5 & 0.1 & 82 & 0 & 0 \\
\hline & \multicolumn{6}{|c|}{ cv. Cornell 619} \\
\hline & \multirow[t]{4}{*}{ B5 } & 1.0 & 0 & 115 & 7 & 6.1 \\
\hline & & 0.5 & 0 & 110 & 1 & 0.9 \\
\hline & & 1.0 & 0.1 & 90 & 0 & 0 \\
\hline & & 0.5 & 0.1 & 92 & 0 & 0 \\
\hline & \multirow[t]{4}{*}{$1 / 2 \mathrm{MS}$} & 1.0 & 0 & 89 & 0 & 0 \\
\hline & & 0.5 & 0 & 99 & 0 & 0 \\
\hline & & 1.0 & 0.1 & 100 & 0 & 0 \\
\hline & & 0.5 & 0.1 & 92 & 0 & 0 \\
\hline Stage 2 & B5 & 1.0 & 0 & 96 & 5 & 5.2 \\
\hline \multirow[t]{7}{*}{ (Uninucl aate) } & & 0.5 & 0 & 102 & 0 & 0 \\
\hline & & 1.0 & 0.1 & 106 & 0 & 0 \\
\hline & & 0.5 & 0.1 & 104 & 0 & 0 \\
\hline & $1 / 2 \mathrm{MS}$ & 1.0 & 0 & 96 & 0 & 0 \\
\hline & & 0.5 & 0 & 102 & 0 & 0 \\
\hline & & 1.0 & 0.1 & 108 & 0 & 0 \\
\hline & & 0.5 & 0.1 & 108 & 0 & 0 \\
\hline
\end{tabular}

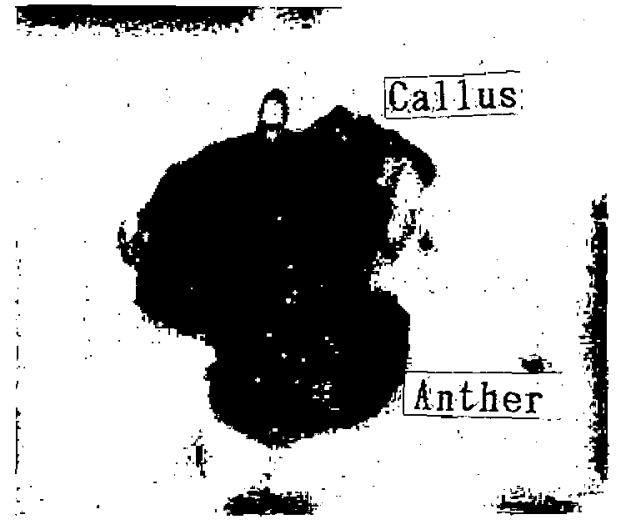

Fig. 2. Callus formation in anther culture.

'Cornell 19', one and three adventitious embryos differentiated from calli on $M S$ basal medium and

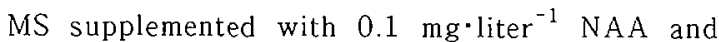

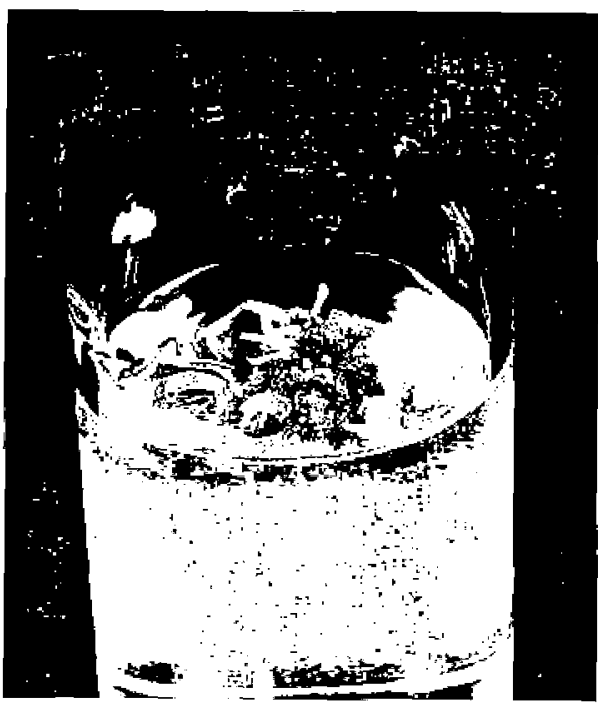

Fig. 3. Adventitious embryos regenerated from callus. 
Table 2. Generation of embryoids from microspore-derived callus on 23 different media.

\begin{tabular}{|c|c|c|c|}
\hline \multicolumn{2}{|c|}{$\begin{array}{l}\text { Phytohormones } \\
\text { in media }(\mathrm{mg} / l)\end{array}$} & \multicolumn{2}{|c|}{ Generation of embryoids } \\
\hline NAA & $\mathrm{BA}$ & cv. Cornell 19 & cv. C. 619 \\
\hline \multirow[t]{7}{*}{0} & 0 & $t^{2}$ & $t^{y}$ \\
\hline & 0.1 & - & - \\
\hline & 0.2 & - & - \\
\hline & 0.4 & - & - \\
\hline & 0.8 & - & - \\
\hline & 1.0 & - & - \\
\hline & 1.6 & - & - \\
\hline \multirow[t]{6}{*}{0.05} & 0.1 & - & - \\
\hline & 0.2 & - & - \\
\hline & 0.4 & - & - \\
\hline & 0.8 & - & - \\
\hline & 1.0 & - & - \\
\hline & 1.6 & - & - \\
\hline \multirow[t]{5}{*}{0.1} & 0.1 & $+^{x}$ & - \\
\hline & 0.2 & $+^{x}$ & - \\
\hline & 0.4 & $+^{x}$ & - \\
\hline & 0.8 & - & - \\
\hline & 1.6 & - & - \\
\hline \multirow[t]{5}{*}{1.0} & 0.1 & - & - \\
\hline & 0.2 & - & - \\
\hline & 0.4 & - & - \\
\hline & 0.8 & - & - \\
\hline & 1.6 & - & - \\
\hline
\end{tabular}

${ }^{z}$ One embryoid regenerated from microspore callus cultured in $1 / 2 \mathrm{MS}+1.0 \mathrm{mg} / \mathrm{l} 2,4-\mathrm{D}$ medium.

$y$ Five embryoids regenerated from microspore callus cul. tured in $B 5+1.0 \mathrm{mg} / \mathrm{l} 2,4-\mathrm{D}$.

$x$ Three embryoids regenerated from microspore callus cultured in $\mathrm{B} 5+1.0 \mathrm{mg} / \mathrm{l} 2,4-\mathrm{D}$.

$0.1,0.2$ and $0.4 \mathrm{mg} \cdot \operatorname{liter}^{-1} \mathrm{BA}$, respectively, after 40 to 60 days. These embryos grew into normal plantlets upon transfer to the same fresh media.

\section{Isolated microspore culture}

Cell division of 'Cornell 619' uninucleate microspores was observed in 3,2 , and 3 petri-dishes out of 5 supplied with B5, NLN, and $1 / 2$ MS media, respectively (Table 3 ). Formation of heartshaped embryos (Fig. 5) was observed in 2 petridishes with B5 medium and 2 petri-dishes with $1 / 2$ MS medium, but the embryos did not grow into plantlets.

Nearly all microspores plated in Medium III formed colonies (Fig. 6) which developed to calli in 3 out of 5 petri-dishes. In microspores plated in other media, less than $30 \%$ initiated cell division,

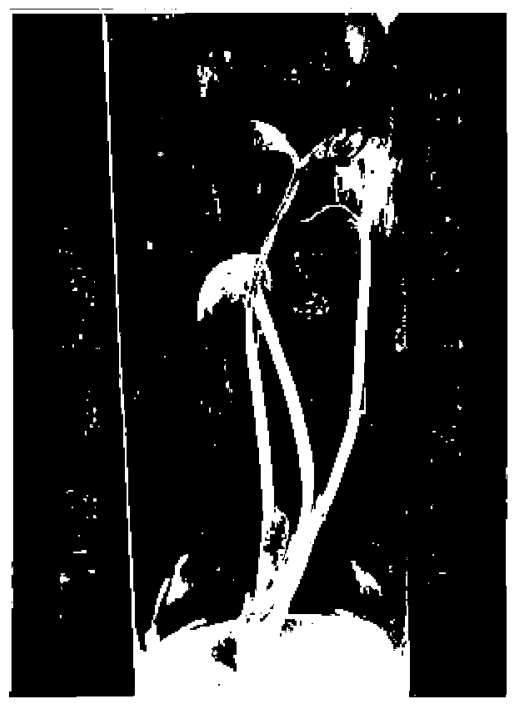

Fig. 4. Normal plantlet from an adventitious embryo.

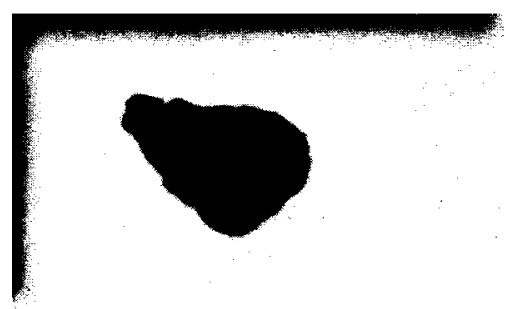

Fig. 5. A heart-shaped embryo from a microspore in isolated microspore culture.

Table 3. Cell division and embryo formation from uninucleat microspores in isolated microspore culture.

\begin{tabular}{lcc}
\hline $\begin{array}{l}\text { Basal } \\
\text { medium }\end{array}$ & $\begin{array}{c}\text { No. of petridishes showing } \\
\text { Cell division }\end{array}$ & $\begin{array}{l}\text { Embryo formation } \\
\text { B5 }\end{array}$ \\
NLN & 3 & 2 \\
$1 / 2 \mathrm{MS}$ & 3 & 0 \\
$1 / 2 \mathrm{MS}$ amino acids & 0 & 0 \\
\hline N & 2 & \\
Number of petridishes showing cell division in micro. \\
spores; $\mathrm{n}=5$.
\end{tabular}




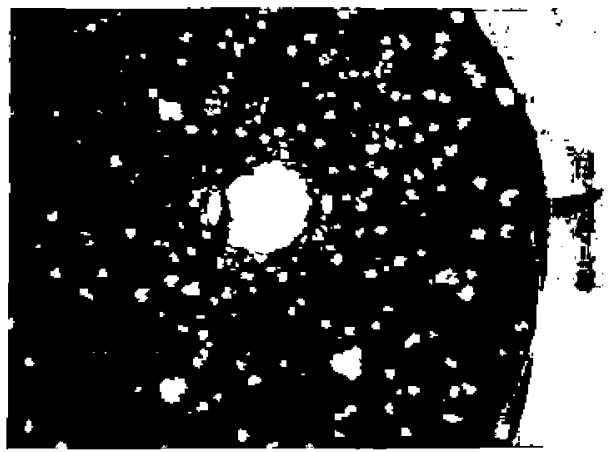

Fig. 6. Colonies and calli formation from microspores in isolated microspore culture.

but they did not develop into calli. Cell division and colony formation in microspores of 'Cornell $19^{\prime}$ were not observed on any medium.

\section{Discussion}

This is the first report on the production of calli and plantlets of celery by anther culture and embryo and callus formation by isolated microspore culture. In anther culture, anther walls or connecting tissues did not form callus, whereas tetrad microspores grew to an uninucleate stage. Although the chromosome number of plants obtained by anther culture was not counted, we believe that calli were derived from microspores and not from somatic tissues. Roots of plants regenerated by anther culture scarcely grew after transfer to vermiculite or soil; some plantlets which did not root flowered in vitro at $25^{\circ} \mathrm{C}$ without vernalization. Therefore, observation of the chromosome numbers in root tips was very difficult. A few plants rooted, but the growth of the roots was slow. Methods of acclimatization in regenerated celery plantlets need to be studied.

A specific character in haploid plant formation of celery is that the embryogenesis and callus formation were induced only in very immature microspores just as in carrot, fennel, and Cryptotaenia japonica (mitsuba) (Matsubara et al., 1995). In most plant species, embryogenesis was inducible in the uninucleate microspores developed in vivo (Bajaj, 1983), but it was induced from tetrad microspores cultures in vitro in Umbelliferae family including celery. Tetrad microspores matured to uninucleate microspores in vitro, then formed embryoids or calli; the stimulus for cell division is not clear. In microspore culture of celery, cell divi. sion occurred directly in uninucleate microspores as in carrot and in more mature microspores.

The composition of the media and concentrations of phytohormones are important factors leading to embryoid and callus formation from anthers but also for subsequent regeneration of plantlets. Microspore embryogenesis of celery can be induced on the media with lower concentrations of minerals than MS, such as B5 and $1 / 2 \mathrm{MS}$ and supplemented with 0.5 or $1.0 \mathrm{mg} / \mathrm{l} 2,4-\mathrm{D}$; BA was ineffective. Celery anther required only 2 , 4-D for androgenesis as in carrot, fennel, and mitsuba (Matsubara et al., 1995).

In microspore culture, B5 and $1 / 2$ MS media were effective as basal media; microspores required 2,4-D and BA for androgenesis. Note that colony and callus formation was affected with a ratio between $\mathrm{NO}_{3}$ and $\mathrm{NH}_{4}$ in a given molarity, $60 \mathrm{mM}$. The most effective ratio of $\mathrm{NH}_{4}$ and $\mathrm{NO}_{3}$ was $1: 3$, and those of $1 / 2$ MS and B5 media which are useful for microspore culture of other plants were $1: 2$ and $1: 12$, respectively. However, these media were ineffective for androgenesis in celery.

For regeneration of embryoids from calli, or plantlets from embryoids, cultures should be transplanted to MS medium without phytohormones. The frequencies of plant regeneration and survival of celery plants after acclimatization were very low, because roots did not develop well as did those of carrot.

\section{Acknowledgement}

This study was supported by a Grant-in-Aid for Scientific Research (C) of the Ministry of Education. No. 0660033.

\section{Literature Cited}

Andersen, S. B., I. Christiansen and B. Farestveit. 1990. Carrot (Daucus carota L.). p. 393-402. p. 393-402. In: Y. P. S. Bajaj (eds.). Bio-technology in agriculture and forestry. Vol. 12. Springer Verlag, Berlin.

Bajaj, Y. P. S. 1983. In vitro production of haploids. p. 229-287. In Evans, D. A., W. R. Sharp, P. V. Ammirato and Y. Yamada (eds.). Hand-book of plant cell culture Vol. 1. McMillan, New York.

Gamborg, O. L., R. A. Miller and L. Ojima. 1968. Requirement of suspension cultures of soybean root 
cell. Exp. Cell. Res. $50: 151-158$.

Hu, K. L., S. Matsubara and K. Murakami. 1993. Haploid plant production by anther culture in carrot (Daucus carota L.). J. Japan. Soc. Hort. Sci. 62 : $561-565$.

Lichter, R. 1982. Induction of haploid plants from isolated pollen of Brassica napus L. Z. Pflanzenphysiol. $105: 427-434$.
Matsubara, S., N. Dohya and K. Murakami. 1995. Callus formation and regeneration of adventitious embryos from carrot, fennel and mitsuba microspores by anther and isolated microspore cultures. Acta Hort. 392 : 129-137.

Murashige, T. and F. Skoog. 1962. A revised medium for the rapid growth and bioassays with tobacco tissue cultures. Physiol. Plant. 914 : 473-497.

葯培養と花粉培養によるセルリ花粉からのカルスと脹様体の形成

銅谷徳夫・松原幸子・村上謙治

岡山大学宸学部 700 岡山県岡山市津島中 1-1-1

摘要

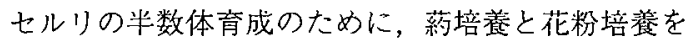
試みた。供試品種として・コーネル 619’と・コーネル 19を用いた。

若い3段階の令の花粉を含む䒺を，1/2 濃度の MS と B 5 培地に2，4-D と BA， $3 \mathrm{~g} \cdot$ liter $^{-1}$ ショ糖，0.2 $\mathrm{g} \cdot \mathrm{liter}^{-1}$ ゲルライトを添加した培地に 5 月から 6 月に かけて植え付けた。

‘ーネル 19’では 4 分子期の花粉から，0.5または $1.0 \mathrm{mg} \cdot$ liter $^{-1} 2 ， 4$-D を添加した $1 / 2 \mathrm{MS}$ または 1.0 $\mathrm{mg} \cdot$ liter $^{-1} 2 ， 4-\mathrm{D}$ を添加したB 5 培地でカルスを形 成した、コーネル 619'では4 分子期の花粉から 0.5 と $1.0 \mathrm{mg} \cdot \mathrm{liter}^{-1} 2 ， 4$-Dを添加したB 5 培地で，1核 期前後の花粉加 $1.0 \mathrm{mg} \cdot \mathrm{liter}^{-1} 2,4$-D添加した
B 5 培地上でカルスを形成した。これらのカルスを NAA と BA を添加または無添加の MS 培地で培養す ることにより，不定胚を再生した，同じ組成のホルモ ンフリー培地へ移植することにより 40 日から 60 日後 に植物体に生育した。

種々の令の花粉を, $2.5 \times 10^{3} / \mathrm{m} l$ 培地の密度で, $\mathrm{B}$ 5 , NLN, $1 / 2$ MS 液体培地で培養した。

‘コーネル 619'では 1 核期前期の花粉からコロニー が形成されたが，B 5 および $1 / 2 \mathrm{MS}$ 培地でのコロニ 一からのみ心臟型胚が再生したがそれ以上には生長し なかった、コーネル 19’では花粉分裂がみられなかっ た。 